\title{
Indentation Hardness and Tribological Wear under the Conditions of Sliding Friction of the Surface Layer of Composites Based on Methacrylate Resins with Ceramic Nanofiller
}

\author{
Daniel Pieniak', Konrad Gauda ${ }^{1 *}$ \\ 1 University of Economics and Innovation in Lublin, Transport and Computer Science Faculty, Projektowa 4, \\ Lublin 20-209, Poland \\ * Corresponding author's e-mail: konrad.gauda@wsei.lublin.pl
}

\begin{abstract}
The biomaterials, which are the subject of this work, are the dental restorative materials classified as light cured polymer matrix ceramic composites or resin based composites. The dental composite materials are needed for the repairment of human teeth. Fillings and other dental applications are exposed to the biomechanical loading in the chewing process. The wear resistance and hardness are important functional properties. Currently, nanofiller composites play an important role among dental composites. The objective of this paper was to study and analyze the friction, mechanical and wear properties of the surface of polymer matrix ceramic filed nanocomposites. Three material groups were used, one commercial composite Filek Z550 (3M ESPE, USA) and two experimental composites Ex-nano(G) and Ex-flow(G). The microindentation tests were conducted on the Micro Combi Tester device (Anton Paar GmbH, Germany). Rotating sliding ball-on-disc friction tests were performed against an alumina ball on $5 \mathrm{~N}$ load at $1 \mathrm{~Hz}$ in the bath of artificial saliva at $37^{\circ} \mathrm{C}$. The linear wear and friction coefficients were evaluated. In the light of the obtained results of contact and friction strength tests, it was found that the performance depends on the production technology of the polymer-ceramic composites. The test results indicate that the share of filler nanoparticles the in experimental composites is advantageous due to the tribological wear.
\end{abstract}

Keywords: nanocomposites, polymer matrix ceramic composites, indentation hardness, wear

\section{INTRODUCTION}

At present, the composite materials play a key role in biomedical applications, aviation industry, automotive and other engineering applications as they show very good properties [3]. Composites are complex materials that contain at least two chemically distinct phases [7]. These phases are clearly separated and the connection of phases occurs at the macroscopic level [16]. The matrix of the composite is a continuous phase, for the polymer composites these are: thermo-, light- and chemosetting resins as well as thermoplastic resins. The reinforcing phase (filler) usually involves the additives that shape the performance properties. The composite, which formed from the combination of phases, has different properties than that obtained by the components separately. The dispersion reinforcement composites are often reinforced by particles (inclusions) and fibers, also natural ones $[4,16,39]$. The performance characteristics depend on the material structure. Among them, the mechanical and tribological characteristics of the surface layer are important. They can be determined experimentally. The indentation method for assessing the mechanical properties of the material surfaces is relatively easy to conduct. The development of an apparatus for indentation tests makes it a useful tool for various measuring systems of different scale (from macro to nano) $[15,17,28]$. The modern apparatus allows for the measurements in the indenter's load range from kilo-Netwons to pico-Newtons and the measurement of the indenter depth in the surface of the 
tested material can be performed with accuracy to nanometers. In addition, the indentation method enables the testing of loose and biological materials as well as nanostructures $[17,31]$.

Abrasion resistance is an equally important functional characteristic of the material that is caused by friction. There are two types of friction, namely: stiction, which is developed to the highest degree at the moment preceding the motion (impending motion) and kinetic friction - after the start of relative motion [9]. The second type of friction is of major importance for the biomaterials that are used to repair the human teeth. From the basics of friction physics, it is known that the contact of cooperating surfaces occurs at the points of elevation of the roughness profile and the actual contact surface is a small fraction of the nominal contact surface [4]. Polymer dental composites are filled with ceramic particles. The dispersed phase of the composite consists of the particles the three spatial dimensions of which are similar. Due to their shape, the reinforcement in this form is sometimes referred to as $3 \mathrm{D}$ reinforcement [23]. The filler usually consists of quartz compounds, ground glass, ceramics and silicon dioxide. The size of the filler particles varies, the size of the pre-polymerized particles as a result of technological process is $1-200 \mu \mathrm{m}$, smaller particle agglomerates $(1-25 \mu \mathrm{m})$, spheroidal fillers $(20-30 \mu \mathrm{m})$ and nanofillers $(<100 \mathrm{~nm})$. The particles of the inorganic phase of polymer-ceramic composites usually contain $70-80 \%$ of glassbased filler and $20-30 \%$ of nanofillers [32]. The zirconium, titanium and aluminum oxide particles of $250-500 \mathrm{~nm}$ are often added. It is obvious that these particles occur on the friction surface and determine the real surface of the bodies in contact and affect the kinetic friction course.

The biomechanics of the chewing process govern the contact of frictional surfaces. Food particles are squeezed and crushed between the opposing teeth and then crushed in the toothfood-tooth contact, which means that there is friction with the participation of three bodies. In the biomechanical process of chewing, there is also a frictional contact of the tooth with the opposing tooth, in the chewing process, in which the tooth penetrates the food particles completely [Delong 2006]. During normal chewing, the occlusive forces are in the range of 5-20 $\mathrm{N}$ and the shape of the curve force - time is close to the positive part of the sinusoidal curve [35]. The tooth speed is from 0.25 to $0.5 \mathrm{~mm} / \mathrm{s}$ and the chewing frequency is in the range of $1-1.5 \mathrm{~Hz}$ [30]. The factors of the oral environment also play an important role for the biotribological behavior; therefore, the tribological tests are also conducted in artificial saliva at a temperature close to physiological one $\left(\sim 37^{\circ} \mathrm{C}\right)[29]$. It follows from the above that the biomechanical loads and physiological environment factors are known. Modern tribometers enable mapping of most of the loads and real factors in laboratory tests. In addition, these methods, as standardized [5,6], allow for the comparison of the results. However, the open data on the mechanical and tribological properties of the dental biomaterials are limited [19]. These properties are important for a clinical success [20]. Therefore, the aim of the research was to gain knowledge about the properties of the surface layer of modern dental composite nanomaterials and conduct a comparative study on these materials.

\section{MATERIAL AND METHOD}

\section{Testing materials}

Three materials were selected for testing: one commercial (Filtek Z550) [40] and two experimental ones (Ex-nano $(\mathrm{G})$, Ex-flow $(\mathrm{G})$ ). The materials are described in Table 1.

The specimens were prepared in accordance with the manufacturers' recommendations. This means that the specimens were shaped by a single operator in a metal split-mold and then light-cured using Megalux LED (Megadenta, Radeberg, Germany) $1200 \mathrm{~mW} / \mathrm{cm}^{2}$ for $40 \mathrm{~s}$ with a soft-start system. After photopolymerization, the specimens were polished with abrasive discs $(600,1200,2400)$ on a single wheel grinder and polisher Saphir 550 (ATM Gmbh, Mammelzen, Germany) equipment and then cleaned in water. All of the tested specimens were immersed in artificial saliva at $37^{\circ} \mathrm{C}$ for 30 days to simulate the aging process.

\section{Indentation hardness test}

The indentation hardness and modulus of elasticity of the surface were determined according to the Oliver-Pharr method [27]. The test was conducted on a Micro Combi Tester device (Anton Paar). The method is described in more detail in [38]. For the calculation of the modulus 
Table 1. Details of tested composites

\begin{tabular}{|c|c|c|c|c|c|}
\hline Material & Manufacturer & Composite type & Matrix (resin) & Filler type & $\begin{array}{c}\text { Filler content } \\
\text { (wt.\%) }\end{array}$ \\
\hline $\begin{array}{c}\text { Filtek Z550 } \\
\text { (abbrev. Z550) }\end{array}$ & 3M ESPE (USA) & $\begin{array}{c}\text { Nanohybrid } \\
\text { composite }\end{array}$ & $\begin{array}{c}\text { BIS-GMA, } \\
\text { UDMA, BIS- } \\
\text { EMA, PEGDMA, } \\
\text { TEGDMA }\end{array}$ & $\begin{array}{c}\mathrm{SiO}_{2} 20 \mathrm{~nm}, \mathrm{ZrO}_{2} / \mathrm{SiO}_{2} \\
5-20 \mathrm{~nm} \text { nanoparticles, } \\
(0.6-1.4 \mathrm{~m} \text { clusters) }\end{array}$ & $82 \%$ \\
\hline Ex-nano(G) & Nano composite & $\begin{array}{c}\text { BIS-GMA, UDMA, } \\
\text { TEGDMA }\end{array}$ & $\begin{array}{c}\text { The inorganic filler particles } \\
\text { consist of barium aluminum, } \\
\text { bore glass and highly } \\
\text { dispersed silicon dioxide, } \\
\text { nanoparticles }\end{array}$ & $82 \%$ \\
\hline Ex-Flow(G) & - & Semi-liquid & BIS-GMA, UDMA, \\
composite & $\begin{array}{c}\text { TEGDMA } \\
\text { comprise silica, dental glass } \\
\text { (strontium aluminum-boron- } \\
\text { silicate glass), nanoparticles }\end{array}$ & $74 \%$ \\
\hline
\end{tabular}

of elasticity of the surface $E_{I T}$, stiffness was determined from the formula (1) [27]:

$$
S=\frac{d P}{d h}=B \cdot(2 / \sqrt{\pi}) \cdot E^{*} \cdot \sqrt{A}
$$

The relationship $\frac{d P}{d h}$ was determined from the graph force - indenter displacement (Fig. 2). In the equation (1), the parameter $\beta$ for the Vickers indenter is 1.0055 [27]. The magnitude $\mathrm{A}$ is a function of the depth $h_{c}$ (Fig. 2) and it is determined on the basis of the following relationship [18]:

$$
\begin{aligned}
A & =F\left(h_{c}\right)=24,54 h_{c}^{2}+C_{1} h_{c}^{1}+C_{2} h_{c}^{1 / 2}+ \\
& +C_{3} h_{c}^{1 / 4}+C_{4} h_{c}^{1 / 8}+\cdots+C_{n} h_{c}^{1 / 2 n}
\end{aligned}
$$

In equation (2), the calculations are based on the constant $C_{n}$, which expresses the indenter's geometry. The method for determining the constant $C_{n}$ is described in the paper [33]. The stiffness calculations include the modulus of the tested surface denoted with the letter $E$. This value is defined by the equation (3):

$$
\frac{1}{E^{*}}=\frac{1-v^{2}}{E}+\frac{1-v_{i}^{2}}{E_{i}}
$$

In the equation (3), the value $E^{*}$ denotes the reduced modulus of elasticity and $v$ - Poisson's ratio, while $E_{i}$ and $v_{i}$ refer to the indenter. Having calculated the stiffness $S$ from the equation (1) and the penetration path of the indenter corresponding to the elastic deformations of the test surface $-h_{c}$, the $E_{I T}$ parameter ( $E$ in the formula 3 ) was calculated from the formula (4):

$$
E_{I T}=\frac{\sqrt{\pi} S}{2 \beta \sqrt{A \cdot h c}}
$$

In some papers, the researchers use the $\mathrm{H} / \mathrm{E}$ [24] (indention hardness $\mathrm{H}_{\mathrm{IT}}$ to the elastic modulus of the surface $\mathrm{E}_{\mathrm{IT}}$ based on $\left.[18,27,33]\right)$. This coefficient combines the ability to the highest possible elastic deformation (low modulus) and the ability to the smallest plastic deformation (high hardness). For many materials, the yield strength $\sigma_{\mathrm{Y}}$ is related to the hardness $\mathrm{H}$ (typical $\mathrm{H} \approx 3 \sigma_{\mathrm{Y}}$ ). The relationship H/E expresses“,,elastic strain to failure" of materials and elastic resilience of material. The higher the $\mathrm{H} / \mathrm{E}$ and $\mathrm{H}^{2} / \mathrm{E}$ ratios, the greater the wear resistance a material should have $[25,26]$.

\section{Sliding wear test}

The sliding wear tests of the resin based composites were conducted using the microtribometer (CSM Instruments SA, Switzerland). The ball-on-disk method was conducted. In the wear tests, a $\phi 6 \mathrm{~mm} \mathrm{Al}_{2} \mathrm{O}_{3}$ ball counterspecimen was used. The parameters of the test: linear speed $18.8 \mathrm{~mm} / \mathrm{s}$, frequency $-1 \mathrm{~Hz}$, normal load $-5 \mathrm{~N}$, friction path $-300 \mathrm{~m}$, temperature $37^{\circ} \mathrm{C}$, medium (bath) - artificial saliva. The number of specimens in each group was $5(\mathrm{~N}=5)$. In this present study, the wear was measured as penetration depth of counterspecimen in a composite specimen. The hardness of the counterspecimen was $2000 \mathrm{HV}$, therefore the ball wear is not evaluated.

\section{RESULTS AND DISCUSSION}

\section{Indentation hardness}

Table 1 summarizes the results of indentation hardness tests. Mean values, standard deviation (Std.Dev.), minimum (Min) and maximum 
(Max) values, sample size $(\mathrm{N})$ and median values are shown. Figure 1 shows the mean "load-penetration depth" indentation curves of all tested materials.

The examination of the indentation hardness according to the Oliver\&Pharr method is based on the registration of normal load and penetration depth in real time [27]. The indentation hardness depends on elastic and plastic deformations. The Z550 material has the highest indentation hardness $\left(\mathrm{H}_{\mathrm{IT}}\right)$. The lowest average value of this mechanical quantity was found in Ex-flow (G) material. A similar relationship was demonstrated for the modulus of elasticity $\left(\mathrm{E}_{\mathrm{IT}}\right)$. Both tested conventional composites with higher filler content were harder and had a higher modulus of elasticity of the surface. The dependence of hardness on the filler content was shown in a number of papers $[10,21]$. A correlation between indentation hardness, modulus of elasticity and the filler content was shown in the paper [15]. Linear regression confirmed a positive correlation between elastic moduli and filler loading (coefficient of determination $\mathrm{R}^{2}=0.98$ ), and between indentation hardness and filler content $\left(\mathrm{R}^{2}=0.99\right)$ [15]. In the paper [15] similar, but not the same, materials were tested. The results of elastic modulus and indentation hardness tests presented in that paper, for similar composites, are similar but slightly higher. However, the hardness tests in that paper, in contrast to those presented here, were conducted with the use of instrumented nanoindentation method, and the samples were stored in distilled water at $37^{\circ} \mathrm{C}$ for 7 days and the light-cured equipment was not the same. In another paper [2], the researchers used the nanoindentation method to determine the hardness and modulus of elasticity of the Filtek Supreme nanocomposite and they were $0.78 \pm 0.17 \mathrm{GPa}\left(\mathrm{H}_{\mathrm{IT}}\right)$ and $15.71 \pm 1.69 \mathrm{GPa}\left(\mathrm{E}_{\mathrm{IT}}\right)$, respectively, which is close to the values obtained for Ex-nano (g) nanocomposite. According to [8], the use of nanoparticles as part of the filler increases the hardness of the material, the Exnano $(G)$ experimental composites contain more nanofiller than Z550. It is possible that the influence of the type and size of filler particles is decisive, yet the type of the dispersed phase is also important, which is different in the tested composites (Table) 1). It is possible that the content of the zirconium particles is important. The studies presented in $[14,36]$ showed that the hardness of the composite increases along with the content of zirconium particles in the material. The hardness of zirconium particles is $17 \mathrm{GPa}$, while other popular filler based on silicon compounds, also used in experimental materials, is about 3-4 GPa [21]. Among the composites tested in this paper, Z550 contains the zirconium oxide particles, which may translate into the highest hardness of this material among those tested.

In some papers, the researchers used the H/E ratio [24] (hardness to modulus of elasticity). This coefficient combines the ability to the highest possible elastic deformation (low modulus) and the

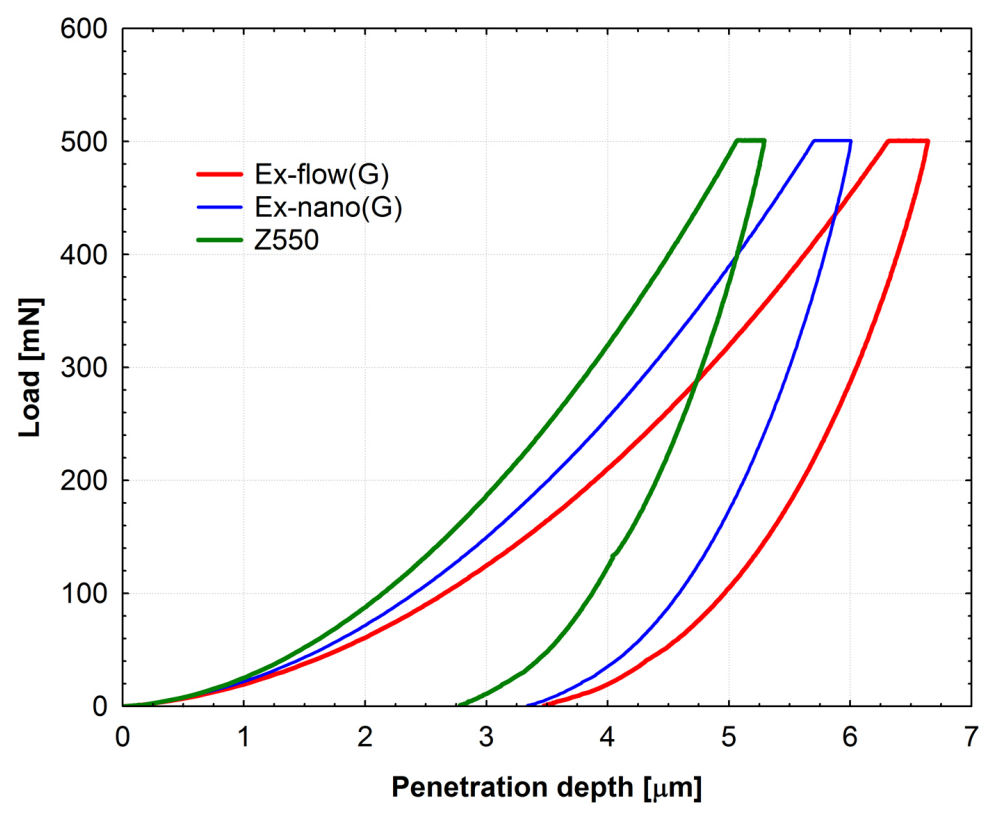

Fig. 1. Mean indentation characteristic (normal load - penetration depth of Vickers indenter) 
Table 2. Descriptive statistics of indentation hardness test results

\begin{tabular}{|c|c|c|c|c|}
\hline Indentation parameters & Statistic parameters & Ex-flow(G) & Ex-nano(G) & Z550 \\
\hline \multirow{6}{*}{$\begin{array}{c}\mathrm{H}_{\mathrm{IT}} \\
{[\mathrm{MPa}]}\end{array}$} & Mean & 602.034 & 726.416 & 984.372 \\
\hline & Std. Dev. & 36.807 & 43.242 & 83.618 \\
\hline & Min. & 534.374 & 673.734 & 815.113 \\
\hline & Max. & 654.48 & 784.703 & 1097.508 \\
\hline & $\mathrm{N}$ & 10 & 10 & 10 \\
\hline & Median & 609.064 & 713.7 & 1018.041 \\
\hline \multirow{6}{*}{$\begin{array}{c}\mathrm{HV}_{\mathrm{IT}} \\
\text { [Vickers] }\end{array}$} & Mean & 56.824 & 68.563 & 92.911 \\
\hline & Std. Dev. & 3.474 & 4.081 & 7.892 \\
\hline & Min. & 50.437 & 63.591 & 76.935 \\
\hline & Max. & 61.774 & 74.065 & 103.589 \\
\hline & $\mathrm{N}$ & 10 & 10 & 10 \\
\hline & Median & 57.487 & 67.363 & 96.089 \\
\hline \multirow{6}{*}{$\begin{array}{c}\mathrm{E}_{\mathrm{IT}} \\
{[\mathrm{GPa}]}\end{array}$} & Mean & 11.603 & 14.686 & 16.588 \\
\hline & Std. Dev. & 0.501 & 0.615 & 0.792 \\
\hline & Min. & 10.446 & 13.753 & 14.466 \\
\hline & Max. & 12.25 & 15.544 & 17.672 \\
\hline & $\mathrm{N}$ & 10 & 10 & 10 \\
\hline & Median & 11.639 & 14.522 & 16.764 \\
\hline
\end{tabular}

ability to the smallest plastic deformations (high hardness). The ratio of hardness to modulus of elasticity (denoted in the literature as $\mathrm{H} / \mathrm{E}$, and in this paper, according to the adopted denotations, refers to the variables denoted as $\mathrm{H}_{\mathrm{IT}} / \mathrm{E}_{\mathrm{IT}}$ ) indirectly determines wear resistance [25]. The following values of this relationship $\left(\mathrm{H} / \mathrm{E} \times 10^{3}\right)$ were obtained: Ex-flow $(G)-51.89$, Ex-nano $(G)-49.46$, Z550 - 59.34. The lowest value was obtained for the conventional Ex-nano(G) resin nanocomposite. The Z550 material had the highest value. As it turns out, there is no correlation between the indentation hardness $\left(\mathrm{H}_{\mathrm{IT}}\right)$ and the $\mathrm{H} / \mathrm{E}$ relationship of experimental materials. The hardness of the composite with a higher content of Ex-nano (G) filler is clearly higher than the hardness of the Ex-flow (G) type composite, and the relationship between the $\mathrm{H} / \mathrm{E}$ ratio of both materials is inverse. The hardness of the conventional Ex-nano $(\mathrm{G})$ composite is $20.66 \%$ higher than Ex-flow (G) and the modulus of elasticity is $26.57 \%$. This is why this ratio is slightly more beneficial for the flow material.

\section{Sliding wear}

Figure 2 presents the box-whiskers of linear wear of the tested composites. The average wear values vary and depend on the material. The Z550 material had the highest average wear. The wear of the experimental materials was similar. The Mann-Whitney statistical test does not reveal any statistically significant differences between the use of experimental materials $(p=0.7540)$. However, the average value of material wear Exflow $(\mathrm{G})$ is lower (similarly as H/E ratio). Other papers revealed smaller wear of flow type composites in the sliding wear tests, but the diversity was greater [29]. This mechanism of increased wear resistance of flow type composites has not yet been explained. The authors of this paper suppose that some particles of the polymer phase of the composite are transferred to the surface of the counter-sample and are applied onto the composite filler particles exposed in the process of wear. According to [1], the transfer film may be in the form of irregular lumps adhering to the smooth counterface, or a continuous uniform layer, which may deform during repeated contact, leading to a smoother counterface.

A friction distance of up to $100 \mathrm{~m}$ has an impact on the variability of the friction coefficient of the tested composites. The course of the friction coefficient variability curves in the range up to $100 \mathrm{~m}$ is monotonic. In the case of experimental materials, the course of the friction coefficient curves is of stationary character in the range of the friction path 100-300 m. The comparison of the curves presented in Figure 3 indicates that the friction coefficient increases the fastest for the Z550 material, which is reflected in sliding wear (Fig. 2). This material was characterized by the highest wear and coefficient of friction. The average friction coefficient for Z550 was 0.58. 


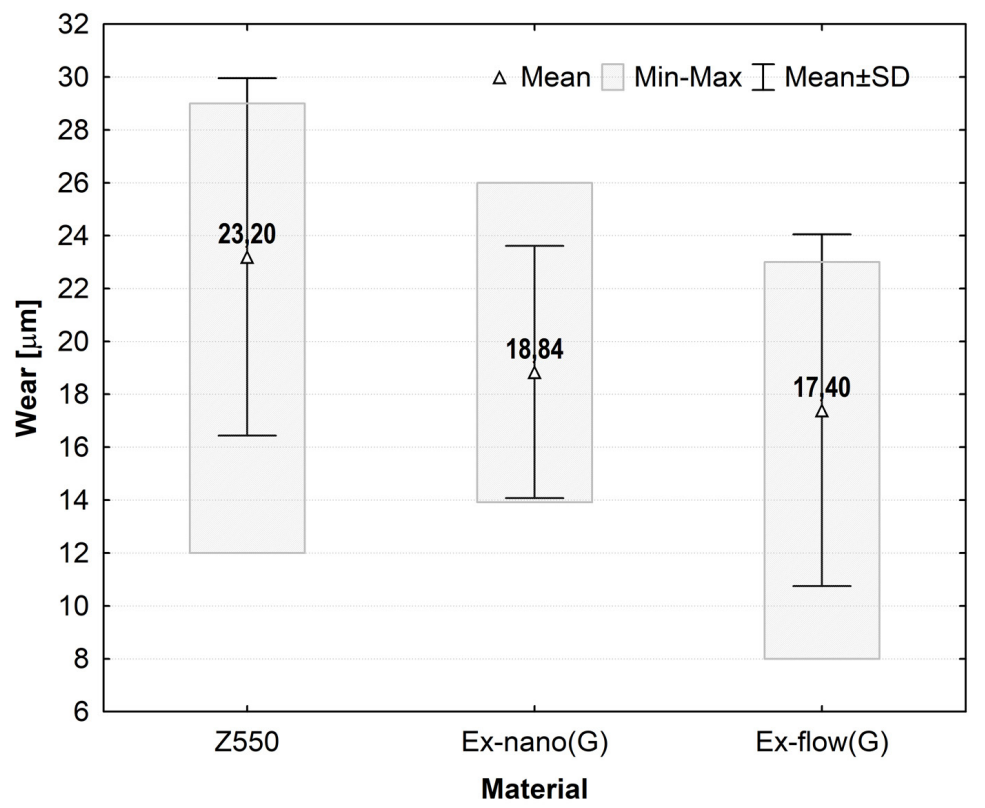

Fig. 2. Box-whiskers chart of linear wear of tested composites

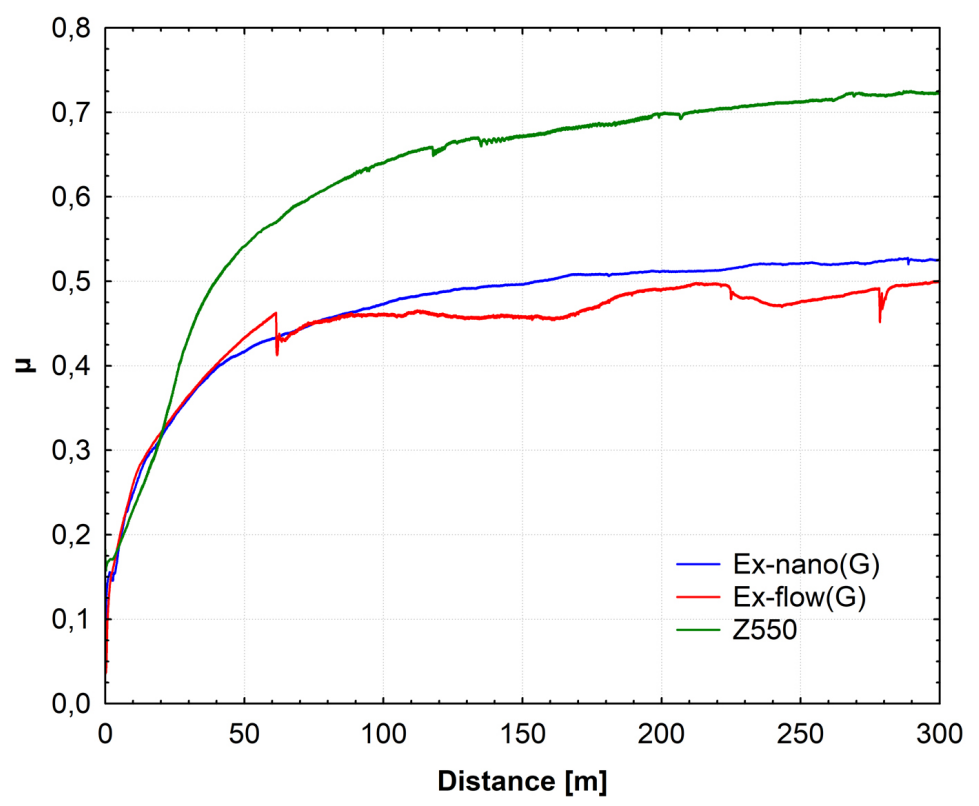

Fig. 3. Representative waveforms of friction coefficient

This means that the average friction coefficient of the experimental materials was $\sim 20 \%$ lower (Table 3). According to [34], too high values of the friction coefficient may lead to premature wear, while too low ones - to lower efficiency in grinding food.

The differences in the wear resistance, shown in these tests, are consistent with the conclusions described in the paper [37]. The author states that the wear depends on the structure of materials in contact and the geometry of the contacts, the interaction conditions in the kinematic pair-loads, stresses, load duration, surface condition and, finally, the environment as well as the working temperature. In addition, the research showed that the value of the $\mathrm{H} / \mathrm{E}$ ratio is not correlated with the resistance to the tribological wear. Therefore, for the newly developed polymer-ceramic dental composites, it is not possible to predict the tribological wear resistance based on the mechanical size of the surface layer.

It seems that the higher wear resistance of the experimental composites depends on the proportion of nanofiller particles, which are greater than 
Table 3. Descriptive statistic of friction coefficient

\begin{tabular}{|c|c|c|c|c|c|}
\hline Materials & Mean & Minimum & Maximum & Std. Dev. & Coef. Var. \\
\hline Ex-nano(G) & 0.46 & 0.41 & 0.51 & 0.05 & 9.87 \\
\hline Ex-flow(G) & 0.45 & 0.40 & 0.48 & 0.03 & 7.70 \\
\hline Z550 & 0.58 & 0.44 & 0.66 & 0.09 & 14.84 \\
\hline
\end{tabular}

in the commercial Z550. There are hypotheses in the specialist literature explaining the effect of nanoparticles. According to Kleczewska [22], the mechanism is as follows, if the sizes of the filler particles and the space between them are smaller than the strains and deformations caused by contact of two bodies, then the material behaves as homogeneous and its wear resistance is similar to the resin base. If the filler particles and the scale of deformations are similar or the filler particles are larger, the material behaves as heterogeneous one, the consumption is lower than the use of the resin base. In addition, according to [12], the improvement of the properties of surface composites is the effect of high proportion of the filler in the matrix and the small particle size, provided they are well dispersed in the material. Large filler particles increase the friction coefficient and thus the friction forces [12], which may also indicate the beneficial effect of nanofillers used in the structure of experimental composites that were tested.

\section{CONCLUSIONS}

On the basis of the literature study and own research, the following conclusions were made:

- In the light of the obtained results of contact and friction strength tests, it was found that the performance depends on the production technology of polymer-ceramic composites.

- The research did not show any correlation between indentation hardness, modulus of elasticity of the surface and the tribological wear. There is also no correlation between the H/E ratio and the tribological wear. Higher hardness does not translate into higher resistance to the tribological wear.

- The research results indicate that the share of the filler nanoparticles in the experimental composites is favorable due to their tribological wear resistance.

- It seems that further development of polymerceramic composites is associated with the recognition of the behavior of a given material under the modeling conditions, as precisely as possible, corresponding to the operating conditions.

\section{REFERENCES}

1. Abdelbary A., 2 - Sliding mechanics of polymers, Editor(s): Abdelbary A. Wear of Polymers and Composites, Woodhead Publishing, 2014, 37-66.

2. Al-Haik M. S., Trinkle S., García D., Yang F., Martínez U., Sumali H. \& Miltenberger S. Investigation of the nanomechanical and tribological properties of dental materials. Int. J. Theoretical and Applied Multiscale Mechanics, Vol. 1, No. 1, 2009

3. Antunes P.V., Ramahlo A., Carrihlo E.V.P. Mechanical and wear behaviours of nano and microfilled polymeric composite: Effect of filler fraction and size. Materials and Design, 61, 2014, 50-60.

4. Ashby M.F., Jones D.R.H. Engineering Materials 2. An Introduction to Microstructures, Processing and Design. 3rd ed., Butterworth-Heinemann, 2006.

5. ASTM Standard G99: Standard Test Method for Wear Testing with a Pin-on-Disk Apparatus.

6. ASTM Standard G132: Standard Test Method for Pin Abrasion Testing.

7. Barton J., Niemczyk A., Czaja K., Korach Ł., Sacher-Majewska B. Kompozyty, biokompozyty i nanokompozyty polimerowe. Otrzymywanie, skład, właściwości i kierunki zastosowań. Chemik, 4 (68), 2014, 280-287

8. Beun S., Glorieux T., Devaux J., Vreven J., Leloup G. Characterizaton of nanofled compared to universal and microfled composites. Dental Materials, 23, 2007, 51-59.

9. Blau P. The significance and use of the friction coefficient. Tribology International, 9 (34), 2001, 585-591.

10. Borba M., Bona A.D., Cecchetti D. Flexural strength and hardness of direct and indirect composites. Brazilian Oral Research, 1 (23), 2009, 5-10.

11. Bucaille J. L., Stauss S., Schwaller P., Michler J. A new technique to determine the elastoplastic properties of thin metal lic films using sharp indenters. Thin Solid Films, 2004, 447-448:239-45.

12. Carreira M., Anunes P.V., Ramahlo A. L., Carrihlo E. Thermocycling effect of mechanical and tribological chracterizaton of two indirect dental restoratve materials. Journal of Brazilian Society of Mechanical Sciences and Engineering, 38, 2016, 5. 
13. DeLong R. Intra-oral restorative materials wear: Rethinking the current approaches: How to measure wear. Dental Materials, 8 (22), 2006, 702-711.

14. dos Reis A.C., de Castro D.T., Schiavon M.A., da Silva L.J., Agnelli M.A. Microstructure and mechanical propertes of composite resins subjected to accelerated artfcial aging. Brazilian Dental Journal, 24 (6), 2013, 599-604.

15. El-Safy S., Akhtar R., Silikas N., Wats D.C. Nanomechanical propertes of dental resin-composites. Dental Materials, 28, 2012, 1292-1300.

16. German J. Podstawy mechaniki kompozytów włóknistych. Wyd. PK, Kraków, 2001.

17. Gouldstone A., Chollacoop N., Dao M., Li J., Minor A.M., Shen Y.L. Indentation across size scales and disciplines: recent developments in experimentation and modeling. Acta Materialia, 55, 2007, 4015-4039.

18. Hardiman M., Vaughan M., McCarthy C.T. The effects of pile-up, viscoelasticity and hydrostatic stress on polymer matrix nanoindentation. Polym. Test., 52, 2016, 157-166.

19. Ikeda H., Nagamatsu Y., Shimizu H. Data on changes in flexural strength and elastic modulus of dental CAD/CAM composites after deterioration tests. Data in brief, 24, 2019, 103889.

20. Ilie N.; Hilton, T.J., Heintze, S.D., Hickel R., Watts D., Silikas N., Stansbury J.W., Cadenaro M., Ferracane J.L. Academy of Dental Materials guidanceResin composites: Part I-Mechanical properties. Dent. Mater, 33, 2017, 880-894.

21. Kim K.H., Ong J L., Okuno O. The effect of fller loading and morphology on the mechanical propertes of contemporary composites. J Prosthet Dent, 87, 2002, 642-649.

22. Kleczewska J., Bieliński D.M. Fricton and wear of resin - based dental materials. Archives Of Civil And Mechanical Engineering, 7(4), 2007, 87-96.

23. Królikowski W., Rosłoniec Z. Nanokompozyty polimerowe. Kompozyty (Composites), 9 (4), 2009, $3-15$.

24. Leyland M.A. The role of nanocomposite coatings in surface engineering. In Proceedings of the 5th International Surface Engineering Congress, Jackson M.J., Eds. ASM International, Washington, USA, 2006.

25. Łępicka M., Grądzka-Dahlke M., Pieniak D., Pasierbiewicz K., Niewczas A. Effect of mechanical properties of substrate and coating on wear performance of TiN- or DLC-coated 316LVM stainless steel. Wear 382-383, 2017, 62-70.

26. Łępicka, M., Grądzka-Dahlke M., Pieniak D., Pasierbiewicz K., Kryńska K., Niewczas A. Tribological performance of titanium nitride coatings: A comparative study on TiN-coated stainless steel and titanium alloy. Wear, 422-423, 2019, 68-80.
27. Oliver W., Pharr G.M.J. Measurement of hardness and elastic modulus by instrumented indentation. Advances in understanding and refinements to methodology. J. Mater. Res., 19, 2004, 1564-1583.

28. Oyen M.L., Ko C.C. Indentation variability of natural nanocomposite materials. Journal of Materials Research, 23, 2008, 760-7.

29. Pieniak D., Walczak A., Niewczas A., Przystupa K. The Effect of Thermocycling on Surface Layer Properties of Light Cured Polymer Matrix Ceramic Composites (PMCCs) Used in Sliding Friction Pair. Materials, 12 (17), 2019, 2776.

30. Sajewicz E., Kulesza Z. A new tribometer for friction and wear studies of dental materials and hard tooth tissues. Tribol. Int. 40, 2007, 885-95.

31. Schuh C.A. Nanoindentation studies of materials. Materials Today, 9, 2006, 32-40.

32. Shalaby W., Shalaby U. Polymers for dental and orthopedic applications. CRC Press, Boca Raton, 2007.

33. Sneddon I.N. The relation between load and penetration in the axisymmetric boussinesq problem for a punch of arbitrary profile. Inter. J. Eng. Sci., $3,1965,47-57$.

34. Szafran M., Cwalińska A., Jałbrzykowski M. Wpływ dodatku nowych rozgałęzionych żywic uretanowo-metakrylowych na właściwości mechaniczne i tribologiczne kompozytów ceramiczno-polimerowych do zastosowań stomatologicznych. Kompozyty (Composites), 8, 2008, 11-14.

35. Zhou1 Z.R. and Zheng J. Tribology of dental materials: a review. J. Phys. D: Appl. Phys, 41, 2008, 113001.

36. Tornavoi D.C., Sato S., Silva L.J., Agnelli J.A.M., dos Reis A.C. Analysis of surface hardness of artfcially aged resin composites. Materials Research, 1 (5), 2012, 9-14.

37. Turssi C.P., De Moraes Purquerio B., Serra M.C. Wear of dental resin composites: Insights into underlying processes and assessment methods - A review. Journal of Biomedical Materials Research B, 65, 2003, 280-285.

38. Walczak A., Pieniak D., Niewczas A., Gil L. Laboratory studies of the influence of thermal cycling on anti-wear properties of composites used in biotribological friction pairs. Tribologia, 280, 2018, 143-149.

39. Ziąbka M., Szaraniec B. Kompozyty polimerowe z dodatkiem włókien naturalnych. Kompozyty (Composites), 2 (10), 2010, 138-142

40. 3M ESPE Filtek Z550 Nano Hybrid Universal Restorative. Technical Data Sheet. Available online: http://multimedia.3m.com/mws/media/7444110/ filtek-z550-technical-data-sheet-cee.pdf (accessed on 1 May 2019). 